2020:5(4):141-149

http://ojs.uho.ac.id/index.php/JIA

doi: http://dx.doi.org/10.37149/JIA.v5i4.12305

\title{
ANALISIS PENDAPATAN DAN PENGARUH PENGGUNAAN INPUT PRODUKSI PADA USAHATANI KEDELAI DI KABUPATEN LOMBOK TENGAH
}

\author{
Dudi Septiadi $^{\left.{ }^{*}\right)}$, Pande Komang Suparyana ${ }^{1)}$, Aeko Fria Utama FR ${ }^{1)}$ \\ ${ }^{1}$ Program Studi Agribisnis Fakultas Pertanian, Universitas Mataram
}

${ }^{*}$ Corresponding author : dudi@unram.ac.id

To cite this article:

Septiadi, D., Suparyana, P., \& Utama FR, A. (2020). Analisis Pendapatan dan Pengaruh Penggunaan Input Produksi Pada Usahatani Kedelai di Kabupaten Lombok Tengah. JIA (Jurnal IImiah Agribisnis) : Jurnal Agribisnis dan IImu Sosial Ekonomi Pertanian, 5(4), 141 - 149. doi:http://dx.doi.org/10.37149/jia.v5i4.12305

Received: June 05, 2020; Accepted: August 30, 2020; Published: August 31, 2020

\section{ABSTRACT}

Soybean is a national strategic food crop commodity with high economic potential. Soybean has many products that are desirable to various classes of society. The development of soybean commodity farming is able to drive the economy in the region. This research intends to investigate the costs and income of soybean farming in Central Lombok District and investigate the elements that affect the production of soybean farming in the Central Lombok District. The data gained in this research are primary data with 30 respondents as farmers. Data were analyzed with the CobbDouglas production function transformed into the regression function. The results revealed that the average total cost spent by farmers was Rp. 3.694.927/Ha and an average total receipt of Rp. 7.008.000/Ha, so that the average total income earned by farmers is Rp. 3.313.073/Ha. Based on the analysis of influence (statistical T-Test), the variable land area, urea fertilizer, and liquid pesticide have had an influence on soybean farm production. Based on F-Test Statistics, together all the independent variables have had an influence on the production of soybean farming in Central Lombok.

Keywords: farming; production; revenue analysis; soybean

\section{PENDAHULUAN}

Salah satu sektor yang memiliki tingkat urgensitas tinggi untuk dikembangkan dalam mencapai pembangunan di daerah adalah sektor pertanian, mengingat karakteristik wilayah Indonesia sebagai negara agraris, dimana mayoritas penduduk memiliki mata pencaharian di sektor pertanian (Nursan \& Septiadi, 2020). (Anriquez \& Stamoulis, 2007) berpandangan bahwa sektor pertanian merupakan bagian penting dalam memacu pertumbuhan perekonomian daerah khususnya di negara sedang berkembang. Sektor pertanian memiliki peran penting dan berkontribusi signifikan dalam pembentuk Produk Domestik Bruto Indonesia. Sektor pertanian memiliki kontribusi besar dalam struktur pembentuk nilai Produk Domestik Bruto (Septiadi \& Joka, 2019). Sepanjang tahun 2014-2018 Sektor Pertanian memberikan kontribusi sebanyak 13,41 persen (BPS, 2018). Kedelai merupakan salah satu komoditas tanaman pangan strategis dalam pembangunan sektor pertanian nasional bersama dengan komoditas padi dan jagung. Kedelai merupakan tanaman pangan yang kaya akan sumber lemak, vitamin, mineral dan protein nabati yang tinggi. Budidaya tanaman kedelai seringkali dilakukan secara perkebunan rakyat dalam bentuk usahatani dengan skala rumahtangga. Sejalan dengan pertambahan jumlah penduduk yang semakin signifikan dan semakin variatifnya jenis makanan olahan hasil komoditas kedelai, maka permintaan kedelai semakin meningkat.

Menurut badan pusat statistik total jumlah penduduk Indonesia mencapai 269 juta jiwa (BPS, 2019). Jumlah penduduk yang banyak berdampak pada permintaan komoditas kedelai untuk konsumsi sangat tinggi. Berdasarkan data secara agregasi nasional menurut (Triastono, Kurniyati, \& Jatuningtyas, 2020) dibutuhkan kedelai sebanyak 2,7 juta ton setiap tahun untuk memenuhi konsumsi dalam negeri. Secara rata-rata pada tahun 2016 konsumsi kedelai diketahui mencapai 9,10 $\mathrm{kg} / \mathrm{kapita} / \mathrm{tahun}$. Tingginya konsumsi kedelai dikarenakan tingginya konsumsi produk olahan kedelai 
contohnya adalah produk panga berupa tempe, susu kedelai, tauco, kecap, tahu, dan bahan baku pakan ternak.

Berdasarkan aspek penawaran, tingkat produksi kedelai dalam negeri tergolong masih rendah (D. Nugraha, Wardana, \& Adnyana, 2018). Saat ini kedelai menjadi produk komoditas dagang dengan jumlah pasokan yang belum memadai untuk kebutuhan domestik. Pemerintah masih melakukan kebijakan impor komoditas kedelai untuk mencukupi kebutuhan dalam negeri. Peluang ini menjadi peluang yang menjanjikan untuk usahatani budidaya kedelai.

Permasalahan yang dihadapi petani dalam menjalankan usahatani kedelai adalah keterbatasan modal dan rendahnya produktivitas tenaga kerja. Persepsi sebagian besar petani yang berpandangan budidaya kedelai hanya untuk tanaman sela berdampak pada tingkat penggunaan teknologi budidaya tanaman kedelai menjadi rendah. Berdasarkan pada faktor eksternal petani, serangan hama penyakit dan kekeringan atau hujan terlalu besar pada saat panen dan kurangnya luas lahan serta kesuburan lahan juga berpengaruh pada produksi kedelai. Kedelai termasuk dalam jenis tanaman kering. Apabila pemeliharaan kurang baik, perkembangan tanaman kedelai akan mendapat hambatan dari pertumbuhan gulma, sehingga akan berdampak pada penurunan hasil panen (G. P. Sari, 2019). Inefisiensi dalam penggunaan faktor produksi merupakan masalah yang dihadapi sebagian besar petani dalam budidaya komoditas kedelai, sehingga budidaya usahatani kedelai tidak berjalan dengan baik (Dewi, Sumba, \& Ambarwati, 2012). Penggunaan input produksi dengan komposisi yang tepat memegang peranan penting dalam usahatani kedelai. Jika komposisi penggunaan input produksi kurang tepat akan berdampak pada rendahnya output yang dihasilkan. Implikasi dari produksi yang rendah mengakibatkan rendahnya pendapatan petani. Selain itu, dinamika harga input juga berpengaruh pada produksi dan pendapatan petani, dimana peningkatan harga input berdampak pada peningkatan biaya produksi, sehingga berimplikasi pada berkurangnya keuntungan yang diterima Petani (Rahayu \& Riptanti, 2010). Selain itu, dinamika harga output kedelai juga bisa menimbulkan masalah jika harga output (produk) mengalami penurunan. Hal ini dikarenakan penerimaan dan keuntungan petani ditentukan oleh harga input dan output (Kurniati, 2015). Usahatani kedelai akan mampu meningkatkan keuntungan yang maksimum manakala petani mampu menggunakan faktor produksi secara efisien (Soekartawi, 2003).

Salah satu kawasan sentra produksi kedelai di Provinsi Nusa Tenggara Barat adalah Kabupaten Lombok Tengah dengan Luas areal 12.036 hektare. Luas areal tanaman kedelai di Kabupaten Lombok Tengah merupakan areal tanam terluas di Pulau Lombok. Harga jual kedelai juga dianggap cukup memuaskan, sehingga membantu meningkatkan tingkat ekonomi para petani. Lombok Tengah memiliki potensi yang cukup baik menjadi sentra industri benih dan budidaya kedelai, dikarenakan memiliki potensi lahan yang luas dan belum dieksplorasi. Disisi lain (Mulyani, Nursyamsi, \& Las, 2014) menyatakan dalam hasil penelitiannya bahwa dari 13,3 juta hektar lahan kering iklim kering yang ada di Indonesia, terdapat sekitar 1,5 juta hektar berada di NTB. Temuan ini menegaskan bahwa ketersediaan lahan kering untuk pengembangan usahatani kedelai masih sangat besar, sehingga perlu mendapat perhatian serius para stakeholder dalam mengembangkannya. Pengembangan budidaya usahatani kedelai memiliki potensi yang menjanjikan. Hanya saja ketersediaan air menjadi faktor penghambat pada budidaya pada lahan kering, mengingat curah hujan yang sangat rendah. Penjelasan tersebut mendorong penulis untuk mengkaji lebih dalam terkait upaya peningkatan produksi usahatani kedelai pada lahan kering seperti di Kabupaten Lombok tengah dengan mempertimbangkan faktor-faktor input produksi yang mempengaruhinya. Berdasarkan penjelasan tersebut, maka penelitian ini tertarik dalam melakukan penguatan dari teori produksi terhadap usahatani kedelai. Penelitian ini bertujuan untuk menyelidiki besaran biaya dan pendapatan usahatani kedelai di Lombok Tengah dan menyeldiki faktor-faktor yang diduga berpengaruh pada produksi kedelai di Lombok Tengah.

\section{MATERI DAN METODE}

Penelitian dilaksanakan di Kabupaten Lombok Tengah Provinsi Nusa Tenggara Barat. Terdapat 2 Kecamatan yang dipilih secara Purposive Sampling. Kecamatan tersebut adalah Kecamatan Pujut dan Praya Barat dengan pertimbangan bahwa daerah tersebut memiliki produksi kedelai yang paling banyak. Penentuan jumlah petani pada usahatani kedelai dilakukan dengan teknik "Quota Sampling" sebanyak 30 petani. Responden di masing-masing Desa ditentukan secara "Proporsional Sampling". Penentuan petani responden yang akan diteliti dilakukan secara "Accidental Sampling" (Sugiyono, 2004). Rumus yang digunakan untuk menganalisis pendapatan usahatani kedelai adalah sebagai berikut: 
Keterangan:

$$
\mathrm{I}=\mathrm{TR}-\mathrm{TC}
$$

I = Pendapatan (Rupiah)

$\mathrm{TR} \quad=$ Penerimaan Total (Rupiah)

$\mathrm{TC}=$ Biaya Total (Rupiah)

Fungsi produksi Cobb-Douglass digunakan untuk menganalisis pengaruh input produksi terhadap hasil produksi usahatani kedelai.

$$
Y=a \cdot X_{1} b_{1} \cdot X_{2} b_{2} \cdot X_{3} b_{3} \cdot X_{4} b_{4} \cdot X_{5} b_{5}
$$

Fungsi tersebut ditransformasiakan ke dalam bentuk linier :

Keteragan:

$\log Y=\log b_{0}+b_{1} \log X_{1}+b_{2} \log X_{2}+b_{3} \log X_{3}+b_{4} \log X_{4}+b_{5} \log X_{5}$

$\mathrm{Y} \quad=$ Produksi Kedelai $(\mathrm{Kg})$

$\mathrm{a} \quad=$ Intersep

$\mathrm{b}_{1}-\mathrm{b}_{5}=$ Koefisien Regresi

$\mathrm{X}_{1}=$ Luas Lahan $(\mathrm{Ha})$

$\mathrm{X}_{2}=\operatorname{Benih}(\mathrm{Kg})$

$\mathrm{X}_{3} \quad=$ Pupuk Urea $(\mathrm{Kg})$

$\mathrm{X}_{4} \quad=$ Pestisida Cair (Lt)

$\mathrm{X}_{5} \quad=$ Tenaga Kerja (HKO)

Uji $R^{2}$, Uji F-test dan Uji T dialkukan untuk mengetahui koefesien determinasi, pengaruh signifikansi dari variabel independen secara bersama-sama dan pengaruh masing-masing variabel bebasnya terhadap variabel terikatnya

\section{HASIL DAN PEMBAHASAN}

\section{Karakteristik Petani}

Peneliti menggali informasi perihal gambaran umum terkait dengan profil dan kondisi objektif di lapangan dari petani sampel. Profil dan kondisi objektif petani kedelai disajikan pada Tabel 1.

Tabel 1. Karakteristik petani kedelai di Kabupaten Lombok Tengah

\begin{tabular}{clcc}
\hline No & \multicolumn{1}{c}{ Rata-Rata Karakteristik Petani } & Keterangan & Satuan \\
\hline 1. & Umur & 52 & Tahun \\
2. & Pendidikan & TSD & Tahun \\
3. & Jumlah anggota keluarga & 4 & Orang \\
4. & Jumlah anggota keluarga yang aktif usahatani & 3 & Orang \\
5. & Pengalaman berusahatani & 20 & Tahun \\
6. & Luas areal lahan kedelai & 0,47 & Ha \\
\hline
\end{tabular}

Sumber: Data primer diolah, 2019

Pada Tabel 1 menggambarkan bahwa petani memiliki rata-rata berusia 52 tahun, artinya petani kedelai di Kabupaten Lombok Tengah masih termasuk dalam usia produktif. Kategori usia produktif ada pada rentang usia 15-64 tahun (BPS, 2019). Temuan ini mengkonfirmasi bahwa profesi petani masih eksis dimana usahatani kedelai dikelola oleh masyarkat pada usia produktif. Meski angka usia ini mendekati akhir usia produktif.

Rata-rata petani menempuh pendidikan adalah Tidak Tamat Sekolah Dasar (TSD). Temuan yang sangat disayangkan dengan rendahnya tingkat pendidikan petani. Padahal menurut (Kuntariningsih \& Mariyono, 2013) salah satu faktor yang berpengaruh pada peningkatan produksi kedelai adalah faktor tingkat pendidikan petani. Upaya untuk meningkatkan pendidikan formal pada para petani dirasa sangat penting, karena hal itu merupakan upaya peningkatan sumberdaya manusia (Kasri, 2011). Selain pendidikan, pelatihan dalam budidaya komoditas kedelai juga harus digalakkan. Menurut hasil penelitian (Kuntariningsih \& Mariyono, 2013) salah satu faktor yang berpengaruh pada peningkatan produksi kedelai adalah faktor pelatihan. Produksi kedelai mengalami peningkatan pasca petani mengikuti program pelatihan budidaya kedelai.

Rata-rata petani memiliki jumlah anggota keluarga sebanyak empat orang. Terdapat tiga orang yang aktif ikut usahatani. Tidak semua anak-anak petani mau terlibat dengan orang tuanya menggeluti profesi petani. Banyak diantara keturunan petani memilih profesi di sektor non pertanian. Hasil ini sejalan dengan hasil penelitian (Wehantouw, Manginsela, \& Moniaga, 2018) yang menjelaskan bahwa salah satu faktor yang menyebabkan keturunan petani memilih profesi di sektor non-pertanian adalah sektor non-pertanian memiliki tingkat upah/gaji yang lebih tinggi dibanding upah 
di sektor pertanian. Diperkuat juga dengan adanya persepsi di masyarakat bahwa orang yang berprofesi di sektor non-pertanian seperti sektor industri dan pendidikan memiliki nilai status sosial yang tinggi.

Petani memiliki pengalaman yang baik dalam usahatani kedelai. Pada Tabel 1 dapat diketahui rata-rata petani sudah 20 Tahun menjalankan usahatnainya. Luas lahan yang dimiliki petani untuk menjalankan usahatani seluas 0,47 Hektar. Banyaknya pengalaman yang dimiliki rata-rata petani kedelai di Kabupaten Lombok Tengah menjadi tanda positif bagi budidaya kedelai di Kabupaten Lombok Tengah. Temuan ini diperkuat hasil penelitian (Tahir, Darwanto, Mulyo, \& Jamhari, 2010) dimana faktor pengalaman berusahatani kedelai memiliki pengaruh pada output produksi kedelai. Jika pengalaman berusahatani kedelai naik 1 persen, maka akan berdampak pada kenaikan produksi kedelai sebesar 0,22 persen.

\section{Biaya dan Pendapatan Usahatani Kedelai}

Biaya yang digunakan petani dalam menjalankan usahatani kedelai ditentukan berdasarkan jumlah pengeluaran uang yang digunakan petani untuk membeli sarana produksi dan upah tenaga kerja. Komponen dari masing-masing biaya disajikan berikut ini;

Tabel 2. Rata-rata biaya sarana produksi pada usahatani kedelai di Kabupaten Lombok Tengah

\begin{tabular}{clcc}
\hline No & \multicolumn{1}{c}{ Uraian } & Biaya $(\mathrm{Rp} / \mathrm{Ha})$ & Persen $(\%)$ \\
\hline 1 & Benih & 200.653 & 8,49 \\
2 & Pupuk Urea & 1.775 .000 & 75,09 \\
3 & Pestisida Cair & 388.167 & 16,42 \\
\hline & Jumlah & 2.363 .820 & 100,00 \\
\hline
\end{tabular}

Sumber: Data primer diolah, 2019

Data diatas menggambarkan pengeluaran saprodi terbesar adalah pada penggunaan pupuk Urea yaitu sebesar $\mathrm{Rp} 1.775 .000 / \mathrm{Ha}$. Pengeluaran petani untuk biaya pupuk urea proporsinya sampai 75,09 persen dari total biaya sarana produksi. Hal ini dikarenakan pupuk Urea diberikan sebagai pupuk dasar. Biaya terbesar kedua adalah pembelian pestisida cair yaitu sebesar Rp $388.167 / \mathrm{Ha}$ dengan proporsi 16,42 persen. Pengeluaran petani untuk biaya pembelian benih tergolong minim, yakni sebesar Rp. 200.653/Ha atau sebesar 8,49 persen dari total biaya saprodi. Berdasarkan temuan penelitian yang ditunjukkan pada Tabel 2, biaya pembelian benih merupakan biaya paling rendah pada input produksi usahatani kedelai. Hal ini mengindikasikan bahwa serangan hama dan penyakit tidak begitu signifikan merusak benih. Benih yang ditanam mampu bertahan dari serangan hama. Petani juga cenderung menggunakan pastisida organik sebagai ramuan petani sendiri. Penggunaan pestisida organik mampu menekan penggunaan pestisida kimia sehingga bisa menghemat biaya. Selain itu, menurut (Tahir et al., 2010) Dosis yang dianjurkan dalam menggunakan pupuk organik adalah 2-5 ton/ha. Penggunaan tersebut memiliki pengaruh positif pada kesuburan lahan dan berimplikasi pada peningkatan produksi kedelai dan peningkatan kesejahteraan petani. Hasil produk dari metode pertanian organik dinilai mampu menghasilkan pangan yang sehat dan bergizi tinggi (Septiadi \& Mundiyah, 2020).

Berdasarkan Tabel 2 dapat menggambarkan bawha pengeluaran yang dihabiskan petani untuk sarana produksi rata-rata sebesar $\mathrm{Rp}$ 2.363.820/Ha. Besaran ini memiliki kesesuaian dengan nominal yang tidak jauh berbeda dengan hasil penelitian (Barokah, 2011) bahwa rata rata biaya sarana produksi pada usahatani kedelai adalah $\mathrm{Rp} 2.336 .842,11 / \mathrm{Ha}$. Komponen biaya kedua adalah biaya tenaga kerja. Penjelasan lebih lanjut dapat dideskripsikan berikut ini:

Tabel 3. Rata-rata Biaya Tenaga Kerja Usahatani kedelai di Kabupaten Lombok Tengah

\begin{tabular}{lccc}
\hline No & Keterangan & Biaya $(\mathrm{Rp} / \mathrm{HKO})$ & Persen $(\%)$ \\
\hline 1 & Tenaga Kerja dari Dalam Keluarga & 649.107 & 51,24 \\
2 & Tenaga Kerja dari Luar Keluarga & 682.000 & 48,76 \\
\hline & Jumlah & 1.331 .107 & 100,00 \\
\hline
\end{tabular}

Sumber: Data primer diolah, 2019

Data diatas menjelaskan bahwa rata-rata pengeluaran petani untuk membiayai tenaga kerja sebesar Rp. 1.331.107/HKO. Persentase biaya untuk tenaga kerja dalam keluarga sebesar 51,24 persen, lebih besar dibandingkan persentase rata-rata biaya untuk tenaga kerja luar keluarga sebesar 48,76 persen. Hasil temuan ini menunjukkan bahwa dibutuhkan tambahan sumberdaya manusai yang berasal dari eksternal keluarga dalam proses produksi usahatani kedelai, meskipun memiliki 
nilai upah yg sedikit lebih tinggi dibandingkan tenaga kerja dari dalam keluarga. Hasil temuan ini didukung penelitian (Fitriadi, Triatmoko, \& Hidayat, 2016) yang menyatakan rata-rata biaya yang berasal dari tenaga kerja luar keluarga (TKLK) sebesar 81.89 persen.

Tenaga kerja dalam keluarga terdiri anggota keluarga diantaranya adalah Istri dan anak petani. Sistem pengupahan tetap diberlakukan untuk tenaga kerja dari dari internal keluarga. Petani mengeluarkan dana untuk tenaga kerja dari internal keluarga rata-rata sebasar Rp 649.107/HKO. Meskipun besarannya masih lebih rendah dibandingkan dengan rata-rata biaya untuk tenaga kerja dari luar keluarga yaitu sebesar Rp 682.000/HKO. Hal ini dikarenakan jumlah tenaga kerja dari luar keluarga lebih banyak diandalkan untuk dipekerjakan dalam setiap kegiatan usahtani sehingga petani mempekerjakan tenaga luar keluarga sesuai dengan kebutuhan petani kedelai. Hasil ini menunjukkan bahwa dibutuhkan tambahan sumberdaya manusia dari eksternal, karena usahatani kedelai dilakukan secara serentak. Berdasarkan penjelasan biaya tersebut, Rata-rata biaya total dari usahatani dijelaskan sebagai berikut ini;

Tabel 4. Biaya total usahatani kedelai di Kabupaten Lombok Tengah

\begin{tabular}{cccc}
\hline No & \multicolumn{1}{c}{ Biaya } & $\mathrm{Rp} / \mathrm{Ha}$ & Persen (\%) \\
\hline 1 & Sarana Produksi & 2.363 .820 & 63,97 \\
2 & Tenaga Kerja & 1.331 .107 & 36,03 \\
\hline & Jumlah & 3.694 .927 & 100,00 \\
\hline
\end{tabular}

Sumber: Data primer diolah, 2019

Berdasarkan data diatas dapat dideskripsikan bahwa total pengeluaran dari petani kedelai dalam menjalankan usaha taninya sebesar Rp. 3.694.927/Ha. Komponen biaya tersebut terdapat biaya saprodi sebesar Rp. 2.363.820/Ha dan biaya tenaga kerja sebesar Rp. $1.331 .107 / \mathrm{Ha}$. Bardasarkan temuan tersebut, biaya untuk sarana produksi merupakan biaya dengan persentasi paling besar yaitu sebanyak 63,97 persen. Besarnya prosentase biaya untuk sarana produksi menandakan bahwa sarana produksi memiliki peran vital dalam proses produksi. Salah satu cara untuk meningkatkan keuntungan dalam usaha tani kedelai adalah dengan menekan biaya input, salah satunya adalah biaya sarana produksi. Sehingga jika harga input produksi mampu ditekan oleh pemerintah maka petani akan memiliki nilai keuntungan yang lebih tinggi. Rata-rata penerimaan usahatani kedelai dapat dihitung dengan cara mengalikan nilai rata-rata output produksi dan harga kedelai.

Tabel 5. Rata-rata penerimaan usahatani kedelai di Kabupaten Lombok Tengah

\begin{tabular}{clc}
\hline No & \multicolumn{1}{c}{ Keterangan } & Per Hektar (Rp) \\
\hline 1 & Produksi (Kg) & 876 \\
2 & Harga Kedelai $(\mathrm{Rp} / \mathrm{Kg})$ & 8000 \\
\hline 3 & Penerimaan $(\mathrm{Rp})$ & 7.008 .000 \\
\hline
\end{tabular}

Sumber: Data primer diolah, 2019

Berdasarkan pada Tabel 5 dapat diungkapkan bahwa rata-rata produksi petani yaitu sebesar $876 \mathrm{~kg} / \mathrm{Ha}$ dengan rata-rata harga kedelai sebesar Rp.8.000/Kg sehingga diperoleh penerimaan petani pada usaha kedelai sebesar $\mathrm{Rp} 7.008 .000 / \mathrm{Ha}$. Setelah nilai rata-rata penerimaan total usahatani kedelai diketahui, selanjutnya adalah mencari nilai pendapatan usahatani. Penjelasan terkait pendapatan yang diterima petani dapat dijelaskan sebagai berikut:

Tabel 6. Rata-rata pendapatan usahatani kedelai di Kabupaten Lombok Tengah

\begin{tabular}{clc}
\hline No & \multicolumn{1}{c}{ Keterangan } & Per Hektar (Rp) \\
\hline 1 & Penerimaan Usahatani & 7.008 .000 \\
2 & Biaya Usahatani & 3.694 .927 \\
\hline 3 & Pendapatan Usahatani & 3.313 .073 \\
\hline
\end{tabular}

Sumber: Data primer diolah, 2019

Berdasar pada Tabel 6, dapat dijelaskan petani memperoleh penerimaan dari usahatani kedelai rata-rata sebanyak $\mathrm{Rp} 7.008 .000 / \mathrm{Ha}$, sedangkan pengeluaran petani untuk biaya usahatani rata-rata sebanyak $\mathrm{Rp} 3.694 .927 / \mathrm{Ha}$, sehingga petani memperoleh pendapatan bersih rata-rata sebanyak Rp 3.313.073/Ha. Nilai yang tidak terlalu besar, dikarenakan produksi yang dihasilkan dalam 1 hektar lahan tergolong tidak terlalu tinggi yaitu $876 \mathrm{~kg}$ saja. Besaran pendapatan petani kedelai di Lombok Tengah didukung hasil penli (Mapu, Antara, \& Muis, 2019) yang mengungkapkan 
bahwa petani kedelai di Kabupaten Tojo Una-una menerima pendapatan bersih sebanyak Rp. 3.570.964/ha. Hal tersebut dikarenakan output produksi per hektar masih belum terlalu besar. Berbeda dengan didaerah lain yang lebih baik dari segi lahan, ketersediaan air dan pengelolaanya seperti hasil penelitian (Ambarita, Prasmatiwi, \& Nugraha, 2014) yang menjelaskan bahwa total pendapatan usahatani kedelai di kabupaten Lampung Selatan sebesar Rp. 5.565.571. Pendapatan petani kedelai tergolong besar dikarenakan total produksi setiap 1 hektar lahan sebesar $1.588 \mathrm{Kg} / \mathrm{Ha}$. Begitu juga dengan petani kedelai di kabupaten Tanah Laut, dimana petani mampu memproduksi rata - rata kacang kedelai dalam satu musim sebanyak $1.272 \mathrm{Kg} / \mathrm{Ha}$ kedelai kering dengan rata-rata penerimaan total setiap petani sebanyak Rp. 5.067.504 (Fitriadi et al., 2016).

\section{Pengaruh Faktor-Faktor Produksi pada Hasil Produksi Kedelai}

Faktor produksi pada penelitian ini terdiri dari luas lahan, benih, pupuk urea, pestisida cair, dan tenaga kerja. Untuk menganalisis faktor produksi tersebut menggunakan nilai koefisien determinasi, uji-t statistics dan uji-f statistics pada persamaan yang sudah ditransformasi dalam bentuk logaritma natural.

Tabel 7. Hasil analisis pengaruh penggunaan faktor-faktor produksi pada usahatani kedelai di Kabupaten Lombok Tengah

\begin{tabular}{lcccc}
\hline \multicolumn{1}{c}{ Variabel } & Koefesien Regresi & T hitung & T-tabel $(\alpha: 5 \%)$ & P-value \\
\hline Luas lahan & 573,1429 & 7,056560 & 2,059 & 0,0000 \\
Benih & $-0,282926$ & $-0,881766$ & 2,059 & 0,3866 \\
Pupuk Urea & 1,924923 & 2,351476 & 2,059 & 0,0272 \\
Pestisida cair & 29,34989 & 2,182140 & 2,059 & 0,0391 \\
Tenaga Kerja & $-1,56 \mathrm{E}-06$ & $-0,092684$ & 2,059 & 0,9269 \\
$\mathrm{R}^{2}$ & $0,93$. & & & \\
Fhitung & 123,8150 & & & \\
P-Value & 0,00000 & & & \\
Sumber: Output E-Views-9, 2019 (data diolah).
\end{tabular}

Berdasar pada Tabel 7, hasil analisis menunjukkan nilai koefisien determinasi $\left(\mathrm{R}^{2}\right)$ sebesar 0,93 . Nilai tersebut memiliki arti bahwa 93 persen keragaman variabel produksi kedelai dapat dijelaskan dengan baik oleh seluruh faktor produksi yang dimasukkan dalam model. Selebihnya sebanyak 7 persen dijelaskan variabel lain di luar model. Variabel di luar model seperti serangan hama, wabah, iklim ekstrim, bencana dan lain-lain. Uji F-Statistic digunakan untuk mengetahui signifikasi variabel independen secara simultan terhadap produksi kedelai. Berdasar pada Tabel 7 , bisa dijelaskan bahwa nilai F-hitung adalah 123,8150, nilai tersebut masih lebih besar dari nilai Ftabel $(2,06)$. Hasil temuan tersebut menggambarkan bahwa seluruh input produksi secara serentak memiliki pengaruh signifikan terhadap produksi usahatani kedelai di Kabupaten Lombok Tengah. Temuan ini sejalan dengan riset (D. A. Nugraha \& Muhaimin, 2018) menunjukkan seluruh faktor produksi usahatani kedelai secara simultan memiliki pengaruh signifikan terhadap produksi kedelai.

Uji T dilakukan untuk melihat pengaruh secara parsial setiap variabel independen terhadap variabel produksi kedelai. Berdasar pada Tabel 7 dapat dijelaskan variabel luas lahan kedelai memiliki pengaruh signifakan secara statistik terhadap produksi kedelai. Hasil tersebut dibuktikan dengan nilai $p$-value 0,0000 , nilai tersebut lebih kecil dari nilai taraf nyata 0,05 . Variabel luas lahan memiliki nilai koefisien regresi sebesar 573.1429. Artinya pengaruh luas lahan terhadap produksi kedelai memiliki pengaruh yang searah. Jika luas lahan bertambah maka produksi kedelai juga akan mengalami kenaikan produksi. Temuan pada penelitian ini sejalan dengan hasil riset dari (Kusumawati, 2010), (Mahabirama, Kuswanti, Daryanto, \& Winandi, 2013) dan (Isnowati, 2014) yang menunjukkan bahwa produksi kedelai dipengaruhi oleh faktor luas lahan.

Berdasarkan pada Tabel 7, variabel pupuk urea dinyatakan berpengaruh signifikan secara statistik terhadap produksi kedelai. Temuan ini dapat dijelaskan dengan melihat nilai $p$-value variabel pupuk urea sebesar 0.0272 , nilai tersebut lebih kecil dari taraf nyata 0,05 . Temuan tesebut menunjukkan bahwa jika ada peningkatan penggunaan pupuk pada taraf tertentu maka produksi kedelai akan mengalami peningkatan. Pupuk urea memiliki nilai koefisien regresi dengan tanda positif sebesar 1,92. Artinya jika pupuk urea dinaikan sebanyak 1 persen, maka akan berdampak pada peningkatan produksi usahatani kedelai sebesar 1,92 persen. Temuan ini didukung oleh hasil riset (Kusumawati, 2010); (Ambarita et al., 2014); (P. M. Sari, Aimon, \& Syofyan, 2014); dan (Tahir et al., 2010), dimana pada penelitiannya menunjukkan bahwa jumlah penggunaan pupuk urea berpengaruh signifikan pada produksi usahatani kedelai. Hasil temuan ini juga menunjukkan bahwa penggunaan pupuk urea masih diperlukan dalam proses produksi usahatani kedelai. Hal ini dikarenakan 
ketersedian unsur hara dalam tanah sering menjadi masalah. Dimana proses recovery unsur hara pada lahan tersebut mengalami perlambatan, bahkan sebagian unsur hara dalam tanah terangkat pasca peningkatan produksi ketika panen. Sehingga proses pemupukan merupakan perlakuan yang penting dalam rangka merangsang pemenuhan unsur hara pada lahan tersebut. Penggunaan pupuk untuk tanaman kedelai berbeda pada setiap jenis lahan. Menurut (Farikin, Suparto, \& Suharyono, 2016) komposisi pupuk yang direkomendasikan pada jenis lahan kering masam terdiri diri dari $50 \mathrm{~kg}$ Urea $+100 \mathrm{~kg} \mathrm{SP}-36+100 \mathrm{~kg} \mathrm{KCl}$ ditambah $500 \mathrm{~kg}$ Dolomit setiap hektar. Kabupaten Lombok Tengah termasuk pada kawasan yang memiliki jenis lahan kering, sehinga hasil penelitian ini menjadi temuan penting sebagai rekomendasi kepada petani dan pihak yang berkepentingan untuk memperhatikan jenis dan dosis pupuk yang digunakan dalam usahatani kedelai.

Variabel pestisida cair mempunyai pengaruh positif dan secara statistik berpengaruh siginifikan terhadap produksi usahatani kedelai. Temuan ini dideskripsikan melalui besaran $p$-value sebesar 0,0391, besaran $p$-value masih dibawah taraf nyata 0,05 . Temuan tersebut didukung hasil riset yang dilakukan (Sahputra, Hasnudi, Rahman, \& Lubis, 2012) di kecamatan beringin Kabupaten Deli Serdang dan penelitian (Rahayu \& Riptanti, 2010) yang menyatakan bahwa variabel pestisida cair berpengaruh nyata terhadap produksi usahatani kedelai. Hasil temuan ini menggambarkan bahwa pestisida memiliki peran penting dalam proses produksi usahatani kedelai, dimana pestisida memiliki kandungan beberapa zat aktif yang dibutuhkan tanaman dalam mengatasi gangguan hama, penyakit dan gulma.

Berdasarkan hasil analisis regresi dengan uji pengaruh bisa dijelaskan pula bahwa terdapat dua variabel yang dinyatakan tidak berpengaruh terhadap produksi usahatani kedelai. Variabel tersebut adalah variabel tenaga kerja dan variabel benih. Hasil penelitian juga menyatakan nilai koefisien tertinggi untuk variabel yang dinyatakan berpengaruh adalah variabel luas lahan. Hasil ini menunjukkan bahwa upaya peningkatan produksi kedelai dapat dilakukan dengan mengupayakan peningkatan luas lahan untuk tanaman kedelai serta melakukan adopsi teknologi. Artinya selain pengelolaan lahan juga penting bagi petani untuk menggunakan teknologi yang lebih baik. Diantaranya adalah penggunaan bibit berkualitas tinggi, penggarapan lahan yang baik, manajemen pengairan dan penggunaan pupuk dengan kualitas baik dan dosisis yang wajar.

\section{KESIMPULAN DAN SARAN}

Petani kedelai mengeluarkan dana untuk biaya total rata-rata senilai Rp. 3.694.927/Ha dengan pendapatan bersih usahatani rata-rata senilai Rp. 3.313.073/Ha. Variabel input produksi yang dinyatakan berpengaruh adalah input luas lahan, pupuk urea dan pestisida cair, sedangkan penggunaan input berupa benih dan tenaga kerja dinyatakan tidak memiliki pengaruh terhadap produksi usahatani kedelai. Sebagai upaya dalam peningkatan produksi kedelai direkomendasikan dengan melakukan penambahan jumlah penggunaan input yang berpengaruh pada peningkatan produksi yaitu variabel luas lahan, pupuk urea dan pestisida cair.

\section{REFERENSI}

Ambarita, M. M., Prasmatiwi, F. E., \& Nugraha, A. (2014). Analisis Efisiensi Produksi Frontier dan Pendapatan Usahatani Kedelai Sekolah Lapangan Pengelolaan Tanaman terpadu (SL-PTT) di Kabupaten Lampung Selatan. Jurnal Agribisnis Fakultas Pertanian, 2(4), 348-355.

Anriquez, G., \& Stamoulis, K. (2007). Rural development and poverty reduction: is agriculture still the key? Working Paper on Research in Agricultural and Applied Economics.

Barokah, U. (2011). Analisis biaya dan pendapatan usahatani kedelai di kabupaten sukoharjo umi barokah. Jurnal SEPA, 8(1), 9-13.

BPS. (2018). Produk Domestik Bruto Indonesia Triwulan 2014-2018. Jakarta.

BPS. (2019). Data Sosial dan Kependudukan Indonesia. Retrieved from https://www.bps.go.id/subject/12/kependudukan.html

Dewi, I., Sumba, I., \& Ambarwati, I. (2012). Analisis Efisiensi Usahatani Padi Sawah (Studi Kasus Di Subak Pacung Babakan, Kecamatan Mengwi, Kabupaten Badung). Journal of Agribusiness and Agritourism, 1(1), 1-10.

Farikin, M., Suparto, S., \& Suharyono, E. (2016). Analisis Usahatani Kedelai Varietas Grobogan di Desa Pandanharum Kabupaten Grobogan. Agromedia, 34(1), 56-63.

Fitriadi, S., Triatmoko, E., \& Hidayat, T. (2016). Analisis Pendapatan Kedelai (Glicine Max L) Di Desa Kunyit Kecamatan Bajuin Kabupaten Tanah Laut Provinsi Kalimantan Selatan. Jurnal Ziraa'ah, 41(1), 33-38. https://doi.org/10.1017/CBO9781107415324.004 
Isnowati, S. (2014). Faktor Yang Mempengaruhi Produksi Kedelai Di Desa Kebonagung Kecamatan Tegowanu Kabupaten Grobogan. Sepa, 10(2), 177-185.

Kasri, R. A. (2011). Time Series Evidence on Education and Economic Growth in Indonesia. Economic Journal of Emerging Markets, 3(2), 109-123. https://doi.org/10.20885/ejem.v3i2.2324

Kuntariningsih, A., \& Mariyono, J. (2013). Dampak pelatihan petani terhadap kinerja usahatani kedelai di Jawa Timur. Jurnal Sosiohumaniora, 15(2).

Kurniati, D. (2015). Perilaku Petani Terhadap Risiko Usahatani Kedelai di Kecamatan Jawai Selatan Kabupaten Sambas. Jurnal Social Economic of Agriculture, 4(1), 32-36.

Kusumawati, H. (2010). Analisis efisiensi ekonomi Penggunaan faktor-faktor produksi Pada usahatani kedelai di kabupaten rembang (Universitas Sebelas Maret). Retrieved from https://digilib.uns.ac.id/dokumen/detail/12647/Analisis-efisiensi-ekonomi-penggunaan-faktorfaktor-produksi-pada-usahatani-kedelai-di-Kabupaten-Rembang

Mahabirama, A. K., Kuswanti, H., Daryanto, S., \& Winandi, R. (2013). Analisis Efisiensi dan Pendapatan Usahatani Kedelai di Kabupaten Garut Provinsi Jawa Barat. JAM: Jurnal Aplikasi Manajemen, 11(2), 197-206. Retrieved from https://jurnaljam.ub.ac.id/index.php/jam/article/view/561

Mapu, C. F., Antara, M., \& Muis, A. (2019). Analisis Pendapatan Usahatani Kedelai di Desa Balingara Kecamatan Ampana Tete Kabupaten Tojo Una-Una. Jurnal Pembangunan Agribisnis, 2(1), $7-12$.

Mulyani, A., Nursyamsi, D., \& Las, I. (2014). Percepatan pengembangan pertanian lahan kering iklim kering di Nusa Tenggara. Jurnal Pengembangan Inovasi Pertanian, 7(4), 187-198.

Nugraha, D. A., \& Muhaimin, A. W. (2018). Analisis Faktor - Faktor Produksi dan Pendapatan Usahatani Kedelai Peserta Program Bantuan Kerjasama Bank Indonesia Kedelai Grobokan (Studi Kasus di Desa Takeranklating, Kecamatan Tikung, Kabupaten Lamongan). Jurnal Ekonomi Pertanian Dan Agribisnis, 2(3), 211-224. https://doi.org/10.21776/ub.jepa.2018.002.03.6

Nugraha, D., Wardana, I. P., \& Adnyana, M. O. (2018). Ketersediaan Kedelai Berdasarkan Peramalan Produksinya dan Beberapa Kendala serta Permasalahannya di Indonesia. Jurnal Penelitian Pertanian Tanaman Pangan, 2(3), 155-163. https://doi.org/10.21082/jpptp.v2n3.2018.p155163

Nursan, M., \& Septiadi, D. (2020). Penentuan Prioritas Komoditas Unggulan Peternakan di Kabupaten Sumbawa Barat. JIA (Jurnal IImiah Agribisnis) : Jurnal Agribisnis Dan IImu Sosial Ekonomi Pertanian, 5(1), 29-34. https://doi.org/10.37149/JIA.v5i1.9789

Rahayu, W., \& Riptanti, E. W. (2010). Analisis Efisiensi Ekonomi Penggunaan Faktor-Faktor Produksi Pada Usahatani Kedelai Di Kabupaten Sukoharjo. Caraka Tani: Journal of Sustainable Agriculture, 25(1), 119. https://doi.org/10.20961/carakatani.v25i1.15758

Sahputra, R., Hasnudi, Rahman, A., \& Lubis, M. M. (2012). Analisis Pendapatan Bersih Petani Kedelai Dan Faktor-Faktor Yang Mempengaruhi Produksi Kedelai di Kecamatan Beringin Kabupaten Deli Serdang. Jurnal Agrica, Universitas Medan Area, 5(2), 66-77.

Sari, G. P. (2019). Efikasi Herbisida Parakuat Diklorida terhadap Pertumbuhan Gulma dan Tanaman serta Hasil Kedelai (Glycine max L. Merr). (Universitas Lampung). Retrieved from http://digilib.unila.ac.id/59781/

Sari, P. M., Aimon, H., \& Syofyan, E. (2014). Analisis Faktor-Faktor Yang Mempengaruhi Impor Kedelai Di Indonesia. Jurnal Kajian Ekonomi, 3(5). https://doi.org/10.22202/economica.2015.v4.i1.261

Septiadi, D., \& Joka, U. (2019). Analisis Respon dan Faktor-Faktor yang Mempengaruhi Permintaan Beras Indonesia. Agrimor, 4(3), 42-44. https://doi.org/10.32938/ag.v4i3.843

Septiadi, D., \& Mundiyah, A. I. (2020). Strategi Pengembangan Usaha Tani Sayuran Berbasis Pertanian Organik. AGRIFO: Jurnal Agribisnis Universitas Malikussaleh, 5(1). https://doi.org/10.29103/ag.v5i1.2743

Soekartawi, A. (2003). Agribisnis; Teori dan Aplikasinya. Jakarta: PT. Raja Grafindo Persada.

Sugiyono. (2004). Metode penelitian Bisnis. Bandung: Alfa Beta.

Tahir, A. G., Darwanto, D. H., Mulyo, J. H., \& Jamhari, N. (2010). Analisis Efisiensi Produksi Sistem Usahatani Kedelai Di Sulawesi Selatan. Jurnal Agro Ekonomi, 28(2), 133-151. https://doi.org/10.21082/jae.v28n2.2010.133-151

Triastono, J., Kurniyati, E., \& Jatuningtyas, R. K. (2020). Status dan Strategi Pengembangan Kedelai Untuk Swasembada di Indonesia. 215-226. Prosiding Seminar Nasional Pertanian Peternakan Terpadu Ke-3, Universitas Muhammadiyah Purworejo. 
Wehantouw, A. D., Manginsela, E. P., \& Moniaga, V. R. B. (2018). Faktor Beralihnya Tenaga Kerja Anak Petani Ke Sektor Non-Pertanian di Desa Treman Kecamatan Kauditan Kabupaten Minahasa Utara. Agri-Sosioekonomi, https://doi.org/10.35791/agrsosek.14.2.2018.20098 